\title{
The effectiveness of cognitive rehabilitation based on executive functions on cognitive performance of slow learner student
}

\author{
Zeynab Gandomi ${ }^{1}$, Ali Akbar Arjmandnia ${ }^{2}$, Gholam Ali Afrooz ${ }^{3}$ \\ 1-PhD Student of Educational Psychology, Department of Psychology, University of Tehran, Tehran, Iran. \\ 2-Associate Professor, Department of Psychology, University of Tehran, Tehran, Iran (Corresponding Author). \\ E-mail: arjmandnia@ut.ac.ir \\ 3- Professor, Department of Psychology, University of Tehran, Tehran, Iran.
}

Received: 20/06/2020

Accepted: 05/08/2020

\begin{abstract}
Introduction: Slow learners have cognitive impairments in attention and memory that effect on learning and problem solving.

Aim: The present study aimed to evaluate the effectiveness of cognitive rehabilitation based on executive functions on cognitive functions in slow learners.

Method: This study was a quasi-experimental study with a pre-test-post-test design with a control group. In this study, the statistical population of all students of late elementary schools who were studying in 2019, among them 30 people were selected from the available schools of Kashan city. The experimental group received 12 sessions of cognitive rehabilitation intervention for 1 hour per week for 3 months. Both groups were evaluated before and after the intervention with working memory test and behavioral rating inventory of executive function (BRIEF). Analysis of Multivariate variance was used for analysis.

Results: The results showed that training package of cognitive rehabilitation could be effective in improving cognitive functions of slow learner student. This improvement in cognitive performance of slow learners student was observed in the components (Initiation, working memory, strategic planning, organizing and monitoring). $(\mathrm{P}<0.001)$.

Conclusion: We can conclude that cognitive rehabilitation based on executive functions improves cognitive function in slow learner based on their performance in cognitive test and the rating of their patents.
\end{abstract}

Keywords: Cognitive rehabilitation, Slow learning, Cognitive functions, Executive function

How to cite this article : Gandomi Z, Arjmandnia AA, Afrooz GA. The effectiveness of cognitive rehabilitation based on executive functions on cognitive performance of slow learner student. Shenakht Journal of Psychology and Psychiatry. 2020; 7 (4): 122-134. URL: http://shenakht.muk.ac.ir/article-1-924-en.pdf

Copyright ( $\odot 2018$ the Author (s). Published by Kurdistan University of Medical Sciences. This is an open access article distributed under the terms of the Creative Commons Attribution-Non Commercial License 4.0 (CCBY-NC), where it is permissible to download, share, remix, transform, and buildup the work provided it is properly cited. The work cannot be used commercially without permission from the journal. 


\title{
بررسى اثربخشى توانبخى شناختى مبتنى بر كاركردهاى اجرايى بر عملكرد شناختى داشى آموزان دير آموز
}

\author{
زينب عندمى'، على اكبر ارجمندنيا؟، غلامعلى افروز” \\ ا.دانشجوى دكترى روانشناسى تربيتى، كروه روانشناسى، دانشكاه تهران، تهران، ايران.

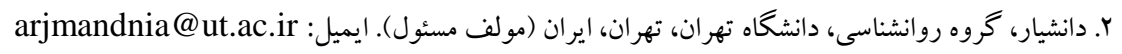 \\ r. استاد، كروه روانشناسى، دانشخاه تهران، تهران، ايران.
}

مقدمه: دانش آموزان دير آموز، داراى اختلالات شناختى در حافظه و توجه هستند كه بر فراگيرى مطالب و حل مسايل آنها تاثير مى كذارد. هدف: يثوهش حاضر با هدف ارزيابى اثربخشى توانبخشى شناختى مبتنى بر كار كردهاى اجر ايى بر عملكرد شناختى در دانش آموزان دير آموز بود.

روش: اين يزوهش از نوع نيمه آزمايشى با طرح ييش آزمون- يس آزمون با خروه كنترل بود. در اين مطالعه جامعه آمارى كليه

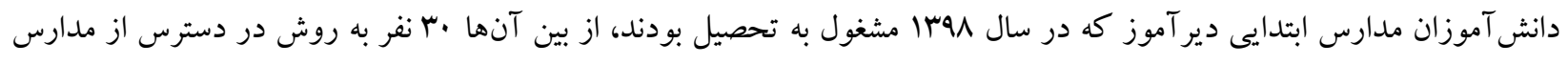

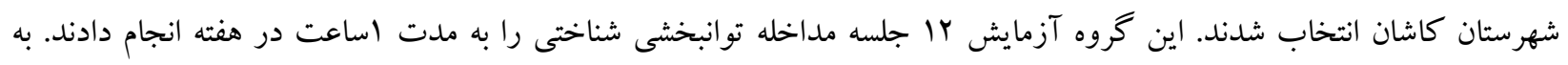

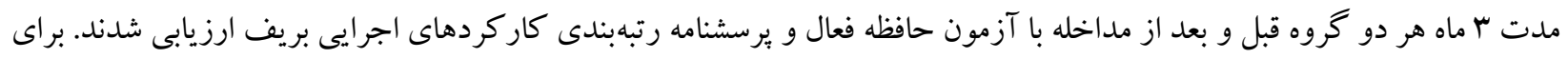
تجزيه و تحليل از واريانس جند متغيره استفاده شد.

يافته ها: نتايج بدست آمده نشان داد، آموزش بستهى توانبخشى شناختى تو انسته در بهبود عملكرد شناختى دانش آموزان دير آموز به

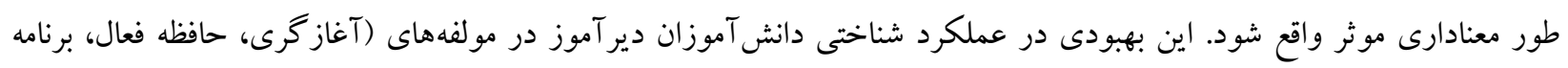

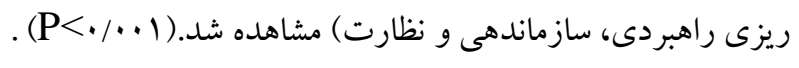

نتيجه كيرى: مى توان نتيجه گرفت كه نوانبخشى شناختى مبتنى بر كار كردهاى اجر ايى براساس عملكرد آنها در آزمون شناختى و

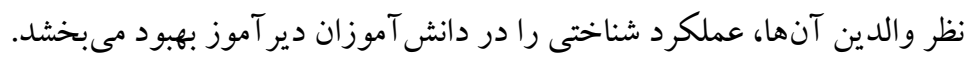
كليدوازهها: تو انبخشى شناختى، دانش آموزان دير آموز، عملكرد شناختى، كار كرد اجرايى 
انتقال مهارت، دانش، استراتزى نسبت به همسالان خود

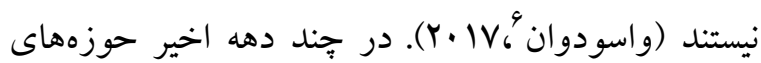
بسيارى در ارتباط با دانش آموزان دجار ناتوانى ياد گيرى،

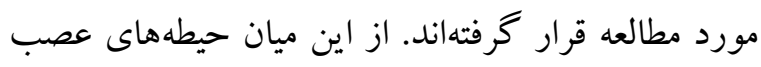
شناختى و شناختى و به ويثه كاركردهاى اجرايى توجه بسيارى از يزوهشخران را به خود جلب كرده است.

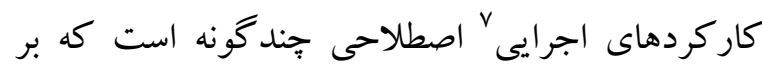
فرايندهاى شناختى متعدد شامل برنامهريزى، حافظه فعال، توجه، بازدارى و خود تنظيمى استفاده مىشود كه اين فرايندها توسط ناحية لوب بيشانى در مغز كنترل مىشوند

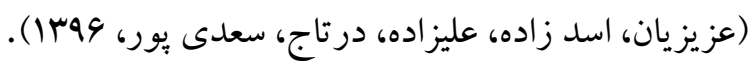
بهطور كلى كاركردهاى اجرايى به كسترهاى از توانايىهاى به هم مرتبط اشاره دارد كه فعاليتهايى از قبيل شروع آكاهانه و ساده يكك رفتار و بازدارى آن تا فعاليت هايى مانند برنامهريزى بيجِيده و حل مسئله را شامل مىشود. مؤلفههاى كاركردهاى اجرايى در عملكرد خواندن و رياضيات تأثير گذار است. اين مؤلفهها همجينين تعيين كنندهى ميزان ييشرفت مهارتهاى تحصيلى و به طور كلى عملكرد فرد در مدرسه هستند. بسيارى از دانشآموزان با ناتوانى يادگيرى در ذخيرهكردن، سازماندهى و اولويتبندى اطلاعات مشكل دارند و به به بهري جاى توجه به مسائل مهم در جزئيات تمركز مى كنند. اين ضعفهاى مطرح شده به عنوان مشكلات در كار كردهاى اجرايى شناسايى مىشوند كه در غالب موارد در مشكلات تحصيلى تظاهر يِيدا مى كند. در نتيجه مىتوان كفت به دليل وجود مشكل در سازماندهى و اولويتبندى جزئيات، حافظه فعال قادر به دست كارى اطلاعات نيست. اين موضوع در كنار نقص در انعطاف يذيرى

${ }^{6}$ - Vasudevan

${ }^{7}$ - Executive functions
مقل مله

دانش آموزان دير آموز' بهره هوشى بين ا تا ب انحراف

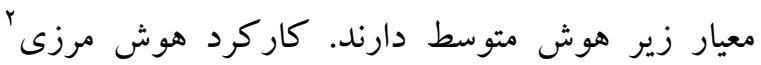
اصطلاحى است براى تفكيك سطح قواى هوشى افراد با عملكرد طبيعى و مستقل در اجتماع از افراد كمتوان ذهنى. اين دسته از دانشآموزان مشكلى در حوزه رفتارهاى سازشى مانند برقرارى ارتباط رفتارهاى

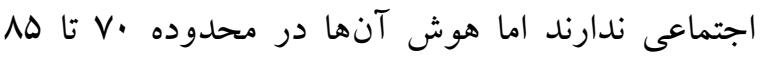

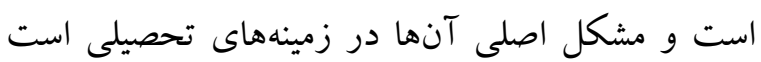

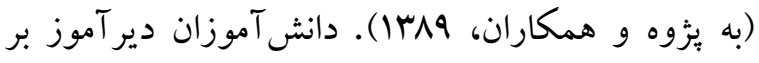
خلاف دانشآموزان با ناتوانى يادكيرى كه از هوش عادى يا بالاتر از عادى برخوردارند، هوش متوسط تا مرزى دارند علاوه بر كاهش نمره هوشى، دانش آموزان دير آموز داراى كنشهاى شناختى بايين و ضعيف در كليه دروس نسبت به دانش آموزان هم سن و سال خود هستند؛ در حالى كه دانش آموزان با ناتوانى يادگيرى داراى كنش هاى شناختى متوسط يا بالاتر بوده و معمولاً

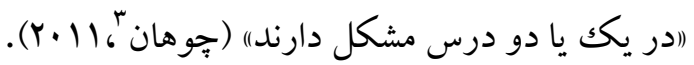
مىتوان جمعيت افراد در اين دامنه هوشى را حدود V درصد تخمين زد. جمعيت دانشآموزان دير آموز در ايران طبق آمار منتشر شده از نتايج سنجش نو آموزان در

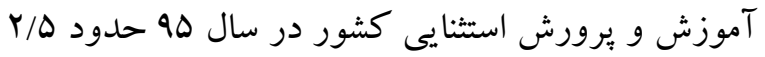

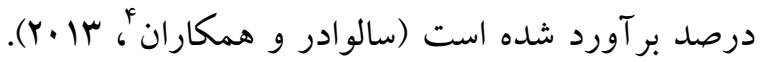
اين دانش آموزان مشكل در درك مفاهيم انتزاعى، نيازمند زمان بيشتر براى دركك مطالب، داراى واز گان محدود

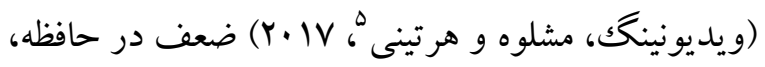
ييدا كردن روابط و شباهت استدلال قادر به تعميم يا

\footnotetext{
1- Slow Learner

${ }^{2}$ - Border Line Intellectual Functioning

3 - Chauhan

${ }^{4}$ - Salvador-Corella,Garcia- Gutierrez

5 - Widyaningtyas, Mashluhah,Hrtini
} 
وجود دارد از اواخر قرن 1/ برنامههاى مختلفى جهت يرورش توانايىهاى شناختى گسترش يافته است كه از اميد بخشترين اين برنامهها، توانبخشى شناختى براى

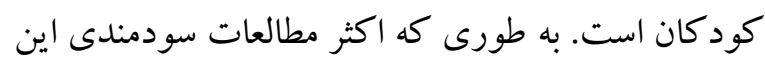
برنامه را نشان مىدهد توانبخشى شناختى يكى روش آموزشى و درمانى براى مشكلات شناختى است كه كاركردهاى آسيب ديده را از طريق راهبردهاى آموزشى، تكرار و تمرين ترميم مى كند به بيان ديكر توانبخشى شناختى مجموعهاى ساختارمند از فعاليتهاى درمانى طراحى شده براى آموزش مهارتهاى مبتى بر حافظه و ساير عملكردهاى شناختى است كه بر پيايه ارزيابى و دركى مشكلات شناختى ارائه شده است (موسى زاده، ارجمندنيا، افروز و غبارى بناب، هوبا). توانبخشى شناختى به افراد كمك مى كند تا نقصهاى شناختى كه خود افراد خانو اده و كار آنها را تحت تأثير قرار داده است برطرف كنند و اين كار را با كمكك يكى متخصص براى شناسايى اهداف شخصى و طراحى راهبردهايى براى رسيدن به آنها، انجام مىدهد. توانبخشى شناختى نوعى تجربه يادگيرى است كه با هدف انطباق كاركردى در فعاليتهاى زندگى روزمره به كار مىرود كه موجب بهبود نقايص و عملكردهاى شناختى از قبيل حافظه، كاركردهاى اجرايى، توجه، تمركز مدنظر قرار مى گيرد (نظرى، دادخواه و هاشمى، . (1)at

نتايج بزوهش الووى يزوهش خود تحت عنوان (احافظه فعال و كاركردهاى اجرايى در دانش آموزان با توانايى هوش مرزى" نشان داد كه دانش آموزان مرزى نقايص كستردهاى در حافظه فعال و كار كردهاى اجرايى دارند.
ذهنى بين مفاهيم انتزاعى و جزئيات مىتواند موجب عدم هماهنكى ميان تو انايى بالقوه و ميز ان عملكرد اين گرووه از دانش آموزان شود (ارجمند نيا و رفيع خواه، سهم|(). كاركردهاى اجرايى به ويزه براى يادگيرى و عملكرد مطلوب در موضوعات تحصيلى بسيار با اهميت است. تأخير در كاركردهاى اجرايى احتمال مشكلات

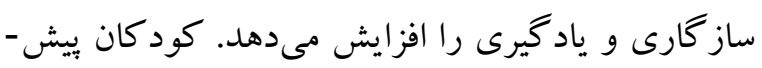
دبستانى با كاركردهاى اجرايى قوىتر در طول تحصيل سطح بالاترى از سواد، لغات و رياضيات را در مقايسه با كائ كود كان با كار كرد عادى اجر ايى ضعيف تر كيب مى كنند

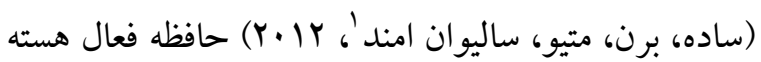
كاركردهاى اجرايى است و رابطه نزديكى با توجه و

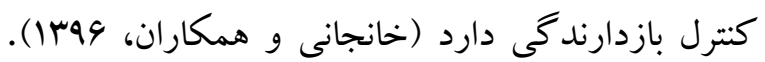
نقص در حافظه فعال فرد را در انجام انواع فعاليتها مانند توجه، برنامهريزى، نخهدارى و سازماندهى اطلاعات، حل مسئله و اجراى اعمال دجار مشكل مىسازد (آمرلند،

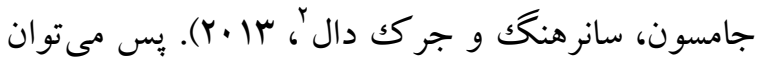
بيان كرد حافظه فعال نقش مهمى در توسعه رشد كودكى و كسب مهارتهاى جديد در حال رشد ايفا مى كند. بررسى نقش حافظه فعال در دانش آموزان با هوش مرزى نشان داده است كه آنان در مقايسه با همسالانشان كشمكش بيشترى با تكاليف حافظهى كو تاه مدت كلامى

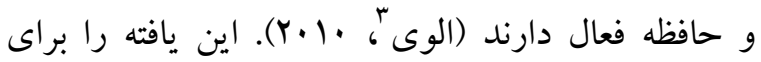
توضيح اينكه دانشآموزان با ناتوانىهاى ياد گيرى صرف نظر از سطح هوششان كار كردهاى حافظهى بايين ترى دارند گسترش دادند (بيرمن، گيرنبر گك و دامتريجَ'

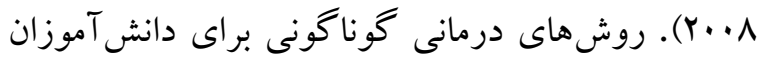

\footnotetext{
1- Sadh,Burn, Matthew, Sullivan, Amend,

2 - Amerland, Esbjomsson'sunnerhagen, \&Bjork dahl

3 - Alloway

4- Biermann، Greenberg, Bilal‘Domitrvich
} 
با نقش مسلمى كه كاركردهاى اجرايى در افزايش مهارتهاى تحصيلى ايفا مى كنند شايسته توجه بيشترى در مداخلات مدرسهاى است به ويثزه براى دانش آموزان ديرآموز كه بيشترين مشكل در حوزه شناخت دارند؛ بنابراين نظر به اهميت توانبخشى شناختى، كاركردهاى

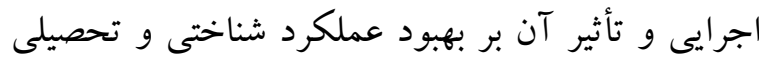
دانش آموزان و هم جنين با توجه به نارسايى در كاركردهاى اجرايى و نقايص شناختى دانشآموزان ديرآموز

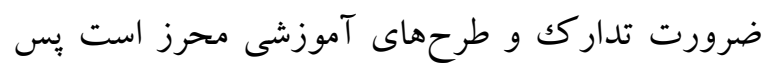
هدف اصلى بثوهش حاضر، تعيين اثربخشى توانبخشى

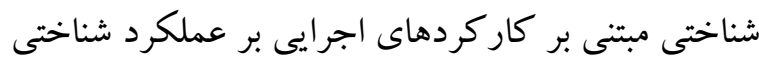
دانش آموزان دير آموز بود.

روش يزوهش حاضر از نوع نيمه آزمايشى با طرح بيش آزمونيس آزمون با گروه كنترل بود. جامعه آمارى در اين

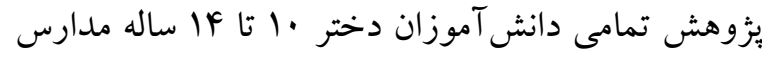
شهر كاشان كه به عنوان دير آموز (مرزى) در سال تحصيلى 1هاן مشغول به تحصيلى بودند كه .ب نفر از آنها با روش نمونه گيرى در دسترس با جاىدهى

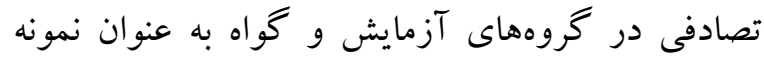
مورد مطالعه انتخاب شدند. معيارهاى ورود دانش آموزان در اين يثوهش بدين شرح بود: داشتن برونده در سامانه صناد، داشتن ضريب هوشى بين · V تا هی، از لحاظ تحصيلى و آموزشى ضعيف و والدين رضايت براى حضور دانش آموزان در اين مطالعه را ارائه كنند. معيار هاى خروج: غيبت بيش از دو جلسه در گروه آموزشى، وجود اختلال يزشكى كه امكان كار را با كودكى با مشكل مواجه مى كند، عدم تمايل به تكميل برسشنامه در
به نظر رويوديكك' سه عامل بازدارى، توجه انتخابى و حافظه فعال مهم ترين مؤلفههاى كاركردهاى اجرايى براى بيشبينى يادگيرى در كودكان هستند. همجنين در

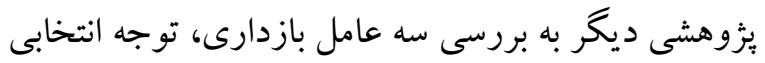
و حافظه فعال مهمترين مؤلفه هاى كاركردهاى اجرايى براى بيشبينى يادگيرى در كود كان هستند نشان داد كه روابط مختلفى بين حافظه فعال رياضى و خواندن در طول

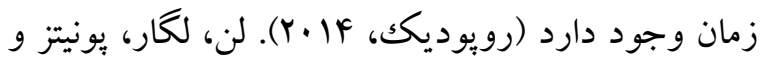

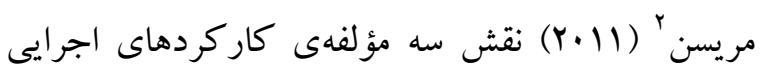
(بازدارى، حافظه فعال و كنترل توجه) در بيشرفت تحصيلى خواندن، رياضيات در كودكان تجينى و و آمريكايى مطالعه شد. در پُزوهش سيخن، لاجيز، ماتى

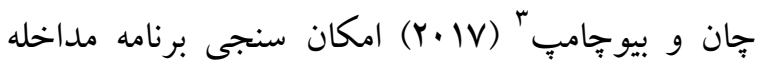
توجهى فشرده و سودبخشى آن يس از آسيب ضربهاى مغز حاكى از ييشرفت در حافظه فعال، بازدارى و و انعطاف يذيرى شناختى در گروه مداخله بود. مطالعه نجار

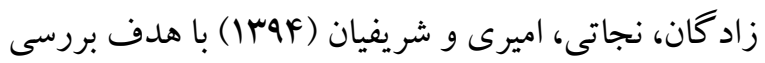
اثر توانبخشى شناختى بر عملكردهاى اجر ايى در كود كان مبتلا به اختلال نقص توجه نشان داد كه توانبخشى شناختى موجب تقويت دقت حافظه فعال شده است.

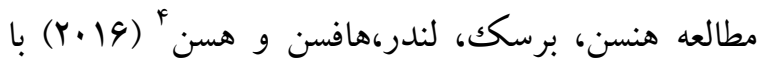
هدف تعيين اثربخشى آموزشى توانبخشى شناختى بر راهبردهاى مقابلهاى اجرايى و شناختى، به زيستى روانى و جنبهاى روانشناختى كيفيت زندگى مرتبط با سلامت در بيماران مبتلا به مولتييل اسكلروزيس نشان داد كه كاركردهاى اجرايى در هر دو گروه به گونهى معنادار

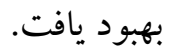

\footnotetext{
1- Roporik

2- Lan, Legare, Ponitz, Morrison

3- Seguin, Lachaise, Matte-Gagne, \&Beauchamp

4- Hanssen, Brisk, Lander, Hofoss, Hessen
} 
ارزياب هاى حاكى از بايايى 9F٪ بر اى مداخلههاى مربوط

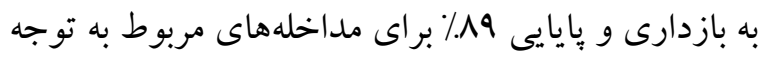
است؛ بنابراين ارزيابهاى بزوهش حاضر توافق بايايى در

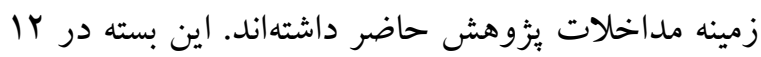

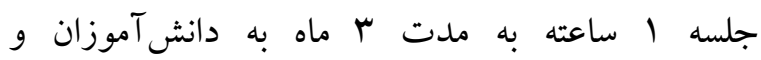
خانوادههاى آنها آموزش داده شد.
يثزوهش حاضر جهت بررسى توافق نظر ارزيابها از روش آمارى همبستخى درون خوشهاى استفاده شد. نتايج بررسى نظرات ارزيابها بدينصورت بود كه يايايى مداخلات حافظه فعال بر ابر با هو٪٪ به دست آمد. اين نشان دهنده توافق عالى بين ارزيابها در زمينه مداخلههاى مربوط به حافظه فعال است. همجينين نتايج بررسى توافق

\section{جلسه 1 جدول ا محتواى جلسات توانبخشى شناختى با تأكيد بر حافظه فعال، توجه مداوم، بازدارى باسخ}

\begin{tabular}{|c|c|c|}
\hline 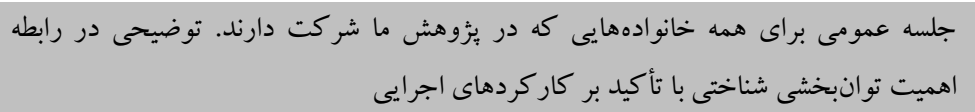 & 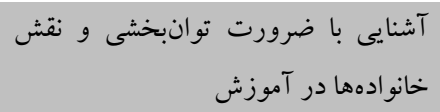 & 1 \\
\hline 1- ا-حافظه فعال r- بازدارى ب- توجه مداوم & 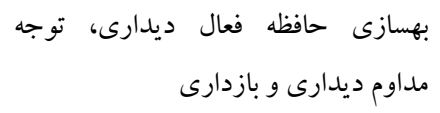 & $r$ \\
\hline مادن تكاليف هفتخى مرينات قبلى و بازخورد خانواده از تمرينات انجامشده و آموزش تمرينها به خانواده و & 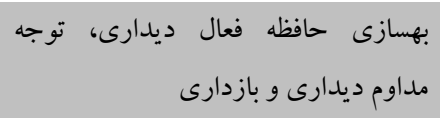 & $r$ \\
\hline 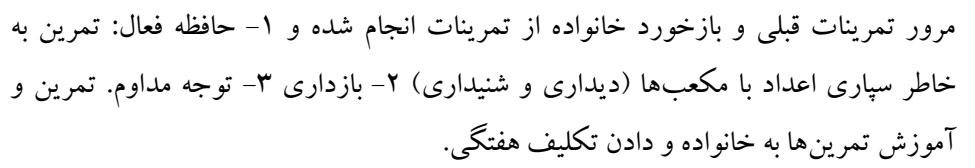 & توجه مدازى حافظه فعال ديدارى و شنيدارى، & $\varphi$ \\
\hline 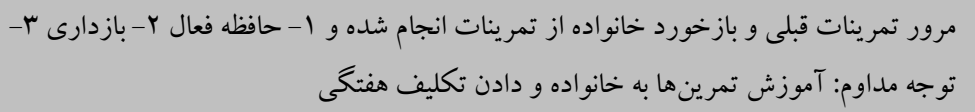 & 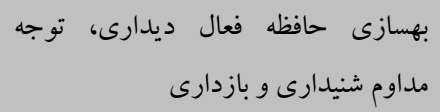 & $\Delta$ \\
\hline مرور تمام تمرينات قبلى (ه جلسه كذشته) و بازخو رد خانواده از تمرينات انجام شده & 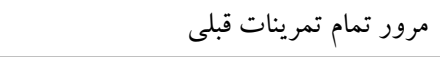 & 4 \\
\hline 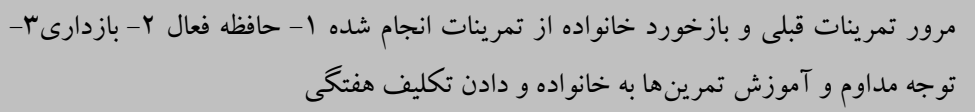 & توجه مدازى حافظه فعال ديدارى و شنيدارى، & r \\
\hline 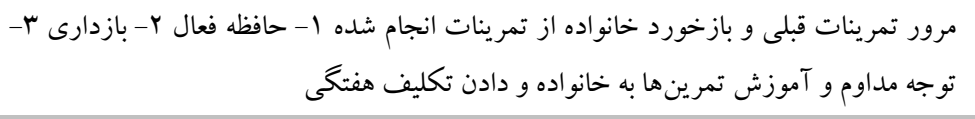 & مداوم ديدارى و شنيدارى، بازدارى ديدارى، توجه & $\wedge$ \\
\hline 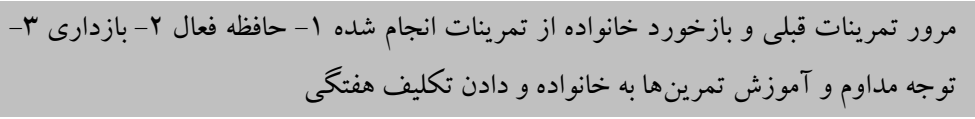 & توجه مدازى حافظه فعال ديدارى و شنيدارى، & 9 \\
\hline 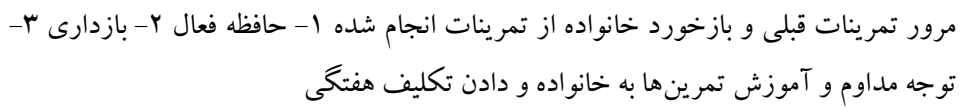 & مداوم ديدارى و بازدارى حافظه فعال شنيدارى، توجه & $1 \cdot$ \\
\hline 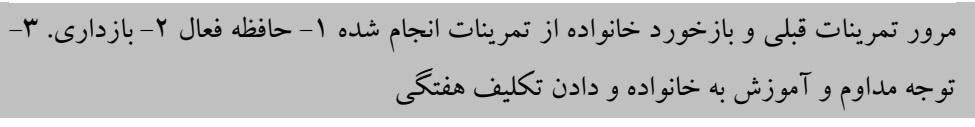 & 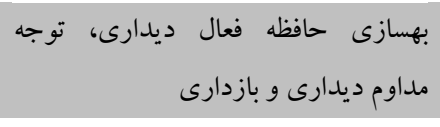 & 11 \\
\hline 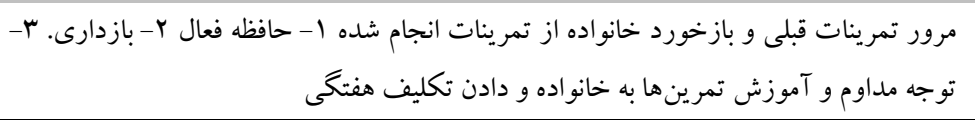 & توجه مدازى حافظه فعال ديدارى و شنيدارى، & it \\
\hline
\end{tabular}

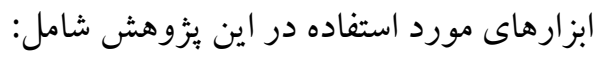


اجراى در سال ·... توسط جيويا، ايسكويت، گُى و كنورسى ساخته شده است، اين بِرسشنامه داراى فرم والدين و معلمان است و هشت مقياس را مورد ارزيابى قرار مىدهد كه عبارتاند از بازدارى، جا جايى توجه، كنترل هيجان، آغازگرى، حافظه فعال، برنامهريزى راهبردى، سازماندهى و نظارت. برسشنامه مذكور يكى آلى از آزمونهاى معتبر و قابل اعتماد است كه به سنجش كاركردهاى اجرايى مى يردازد و در بين ساير يرسشنامه هاى مربوط به كاركرد اجرايى به خاطر اينكه رفتار افراد در زندگى واقعى افراد را مورد ارزيابى قرار مىدهد داراى ارزش فراوانى است نمره گذارى اين برسشنامه به ورديه صورت ليكرت (هركز = صفر، كاهى= يكك و اغلب= دو) است برسشنامه حاضر متشكل از دو شاخص تنظيم رفتار و شاخص شناختى است و هر يكك از شاخص ها داراى زير مؤلفه هايى مىباشند كه به ترتيب عبارتاند از (بازدارى، جابهجايى توجه، كنترل هيجان) و (آغاز گرى، حافظه فعال، برنامهريزى راهبردى، سازماندهى و نظارت) در نهايت مىتوان از تجميع نمرات زير مؤلفهاى را يزوهش نمره كل آزمون بريف را به دست آورد. در تحقيقات انجام گرفته ميانگين آلفاى كرونباخ به دست آمده بين

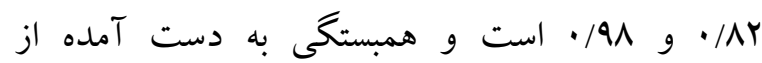
باز آزمايى بعد از r هفته براى مقياسهاى فرم والدين

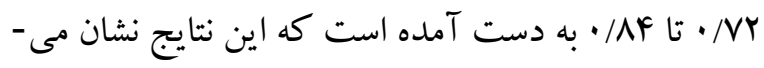
دهد اين برسشنامه از يايايى بهترى نسبت به برسشنامههاى قبلى برخوردار است (عبدالمحمدى و همكاران، وهبا ). بسته توانبخشى شناختى"! بستهاى است كه براى ارتقاى

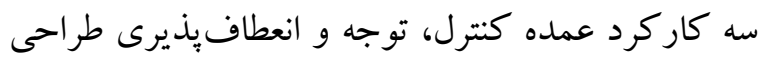
كرديده است. بتا از سروازههاى سه كلمه مذكور ساخته

\footnotetext{
${ }^{3}$ - Cognitive rehabilitation package
}

آزمون حافظه فعال برایى كودكان (WMB_C آزمون را سوزان بيكرينگك و سوزان كدركول در سال

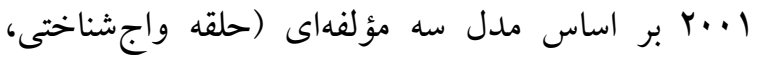
حافظه ديدارى و مجرى مركزى) بدلى و هيج به منظور سنجش حافظه فعال (شناخت و ييشرفت كلى) كود كان و نوجوانان \& تا F ه تا ساله طراحى كردهاند و ارجمند نيا آن را در سال وهبا ترجمه، انطباق و هنجاريابى كرده است (ارجمند نيا، و4سا) آزمون حافظه فعال كه در حدود يكك ساعت به صورت انفرادى اجرا مىشود داراى خرده آزمون يادآورى رقم، تطبيق ليست لغت، يادآورى ليست لغت، ياد آورى ليست هجاهاى بىمعنى، ياد آورى مكعب، حافظه مازها، يادآورى شنيدن، يادآورى شمارش و يادآورى رقم رو به عقب است. اين آزمون عملكرد مؤلفه حلقه واج شناختى را با مجموع نمرات يادآورى رقم، تطبيق ليست لغت، يادآورى ليست لغت و يادآورى ليست هجاهاى بىمعنى؛ عملكرد مؤلفه صفحه ديدارى فضايى را با مجموع نمرات يادآورى مكعب و حافظه مازها و عملكرد مؤلفه مجرى مر كزى را با مجموع نمرات يادآورى شنيدن، يادآورى شمارش و يادآورى رقم رو ما به عقب مورد سنجش قرار مىدهد. مجموع نمره عملكرد فرد در اين سه مؤلفه نيز بهره حافظ فعال را مشخص مى -

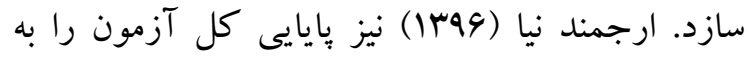

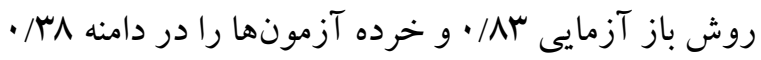

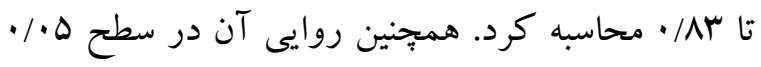
معنادار بود و روايى كل آن را هو/· به دست آورد (عاشورى و تاجور رستمى، 91 1). برسشنامه درجه بندى رفتارى كاركودهاى اجرايع' (BRIEF)

\footnotetext{
1. Working Memory Test Battery-Children

${ }^{2}$ - Behavior Rating Inventory of Executive Function
} 
فعال است. همجنين نتايج بررسى توافق ارزيابهاى

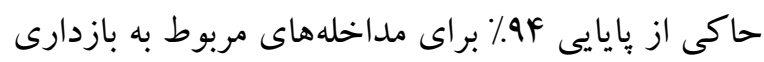

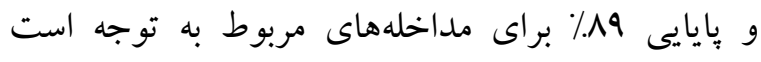

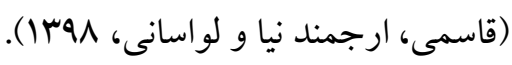

\section{يافتهها}

يافتهاى توصيفى نشان داد كه سن آزمودنىها در كروه

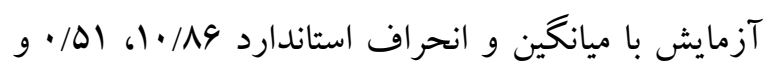

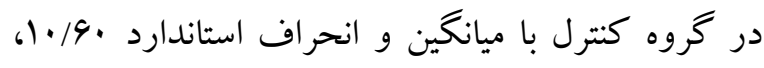

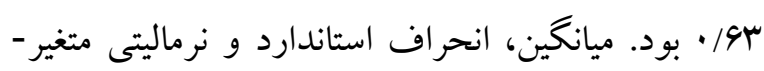
هاى و حافظه فعال و عملكرد شناختى در دو خروه آزمايش و كنترل در موقعيت بيش آزمون و پِ آس آزمون در جدول r آمده است.
شده است. از آن در تقويت كاركردهاى اجرايى كود كان و نوجوانان با اختلال كاستى توجه و بيشفالى التهالى، اختلالات ياد گيرى، اتيسم و ساير افرادى كه در كاركردهاى اجرايى نقص و ضعف دارند استفاده كند. اين بسته شامل سه بخش است در بخش اول تمرينهاى بازدارى

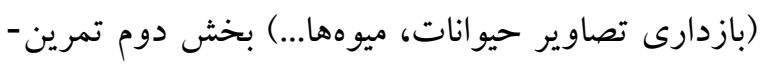
هاى انعطافيذيرى (شامل دستهبندى كارتها، ارائه

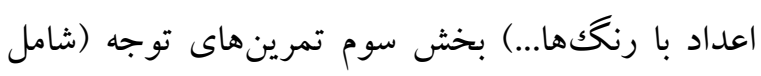
تصوير اعداد بدون ترتيب، تصوير دايره...)؛ كه در سال 1ا 19 توسط ارجمند نيا اثربخشى و كارايى آن تائيد شده

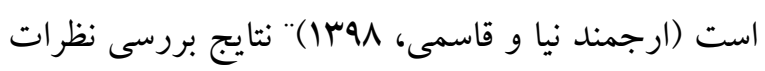

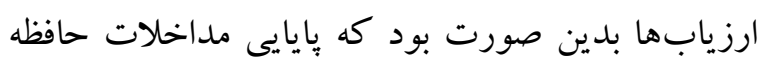

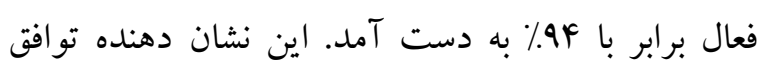
عالى بين ارزيابها در زمينه مداخلههاى مربوط به حافظه

جدول ب شاخصهاى توصيفى نمرات بيش آزمون - بِ آزمون در دو كروه آزمايش و كنترل (n=30)

\begin{tabular}{|c|c|c|c|c|c|c|c|}
\hline عنى سطارى & شإيرو-ويلكز & انحراف معيار & ميانكين & كروه & وضعيت & & متغير \\
\hline $.1 .9 r$ & . /199 & $1 \cdot / F^{2}$ & $99 / 14$ & كنترل & يَيش آزمون & مجرى مر كزى & حافظه فعال \\
\hline.$/ \Delta F$ & - /MF & IY/YY & $90 / 9$. & آزمايش & & & \\
\hline$\cdot / \mu r$. &.$/ 9 \cdot 9$ & $1 . / 99$ & $91 / 99$ & كنترل & بِ آزمون & & \\
\hline $.1 .9 \mathrm{~V}$ & - /A9F & $r q / 1 \Lambda$ & $19 / 49$ & آزمايش & & & \\
\hline$\cdot / 799$ & . & $\mid r / A$. & $9 N 1 \cdot 9$ & كنترل & يِيش آزمون & حافظه ديدارى & \\
\hline$\cdot / \cdot \Delta r$ & - MAr & $18 / 4 F$ & VI/or & آزمايش & & & \\
\hline$\cdot / T V A$ & . /9r. & $\mid F / I r$ & $v \psi / . \cdot$ & كنترل & טֶ آزمون & & \\
\hline$\cdot / r v$ &.$/ 94$. & $10 / F q$ & $1 \cdots / r \mu$ & آزمايش & & & \\
\hline$\cdot / r \Delta 9$ & . /9H人 & $18 / r \Delta$ & $\Lambda \cdot / r r$ & كنترل & يّيش آزمون & واجشناسى & \\
\hline.$/ 919$ &.$/ 99$. & $\mid F / A V$ & va/.. & آزمايش & & & \\
\hline.$/ 999$ &.$/ 91$. & $\mid F / \Delta$. & $\wedge 9 / \cdot$ & كنترل & מֶ آزمون & & \\
\hline .1 .9 & $\cdot / M 9$ & $18 / 99$ & $1 \cdot N / 9 r$ & آزمايش & & & \\
\hline.$/ 491$ & . /949 & $r \cdot / 99$ & $\wedge 9 / \Lambda$. & كنترل & ييش آزمون & شناختى & عملكرد \\
\hline - 1494 & . /9k9 & $I V / F A$ & $9 \cdot / 19$ & آزمايش & & & شناختى \\
\hline
\end{tabular}




\begin{tabular}{|c|c|c|c|c|}
\hline$\cdot / \pi 49$ & . /q४q & $r \cdot / 99$ & Vq/f. & كنترل \\
\hline$\cdot / 0 \cdot 1$ &.$/ 9 F 9$ & 191.9 & $\Lambda q / \Lambda$. & آزمايش \\
\hline
\end{tabular}

بنابراين مفروضههاى آزمون آمارى تحليل كوواريانس

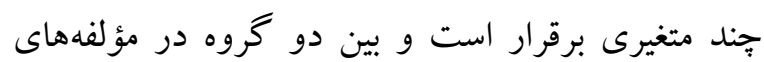
حافظه فعال و عملكرد شناختى تفاوت معنادارى وجود

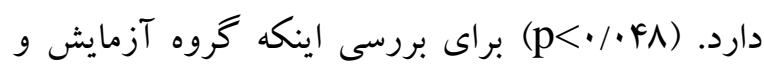
كنترل در كدام يكك از مؤلفهى حافظه فعال و عملكرد شناختى با يكديكر تفاوت دارند در جدول س بنايج تحليل كواريانس تكك متغيرى گزارش شده است.
براى تعيين اثربخشى برنامه مداخلاتى بر عملكرد شناختى،

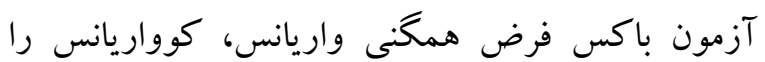

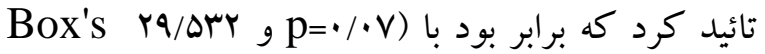

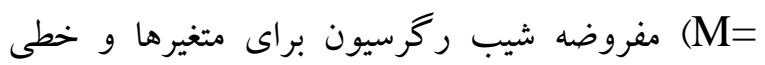
بودن رابطه متغيرها برقرار بود. مفروضه شيب خط ركرسيون براى متغيرها و خطى بودن رابطه متغيرها برقرار بود. نتايج آزمون لون نيز برقرارى فرض همئى بودئ

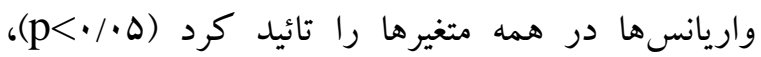

\begin{tabular}{|c|c|c|c|c|c|c|}
\hline اندازه اثر & سطح معنادارى & $\mathbf{F}$ & تفاوت ميانكين & ميانكين & كروه & متغير \\
\hline \multirow{2}{*}{$\cdot / I V I$} & \multirow{2}{*}{.$/ \cdot r$} & \multirow{2}{*}{$\Delta / V q$} & \multirow{2}{*}{$1 V / 9$} & $19 / 19$ & آزمايش & \multirow[t]{2}{*}{ مجرى مر كزى } \\
\hline & & & & $91 / 99$ & كنترل & \\
\hline \multirow{2}{*}{$\cdot / \& \Delta \Lambda$} & \multirow{2}{*}{$\cdot / \cdots$} & \multirow{2}{*}{$r r / q V$} & \multirow{2}{*}{$r 9 / \pi T$} & $1 . . / \mu$ & آزمايش & \multirow[t]{2}{*}{ حافظه ديدارى } \\
\hline & & & & $V F /$. & كنترل & \\
\hline \multirow{2}{*}{ ( } & \multirow{2}{*}{$\cdot / \ldots$} & \multirow{2}{*}{ IN/IY } & \multirow{2}{*}{ rr/ar } & $1 \cdot 1 / 94$ & آزمايش & \multirow[t]{2}{*}{ واج شناختى } \\
\hline & & & & $\wedge 9 / . \cdot$ & كنترل & \\
\hline \multirow{2}{*}{ r/l1 } & \multirow{2}{*}{.$/ .4 \lambda$} & \multirow{2}{*}{ r/grr } & \multirow{2}{*}{$1 \cdot / 4$} & $\wedge 9 / \Lambda$. & آزمايش & \multirow[t]{2}{*}{ شناختى } \\
\hline & & & & $v q / 4$. & كنترل & \\
\hline
\end{tabular}

\section{بحث}

اين يزوهش با هدف بررسى اثربخشى برنامه توانبخشى شناختى مبتنى بر كاركردهاى اجرايى بر عملكرد شناختى دانش آموزان دير آموز انجام شد. اين يافته با نتايج يافته -

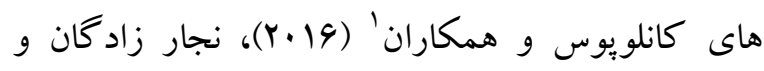

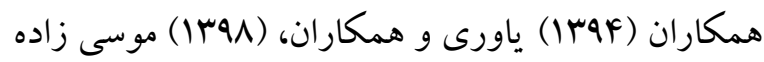

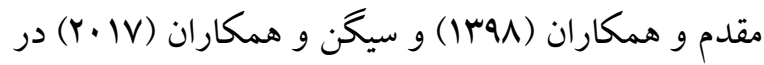

1. Kanellopoulos A, Andersson S, Zeller B, Tamnes C.K, Fjell A.M, Walhovd K.B, Westlye
با توجه به جدول له اثر معنادارى بر نمرات مجرى مركزى (Q/VG)، صفحه ديدارى فضايى (YM/GV) و حلقه واج شناختى (IN/IY) و ش شناختى ( (ه) (p) بر اساس اندازه اثر مى توان بيان كرد به ترتيب

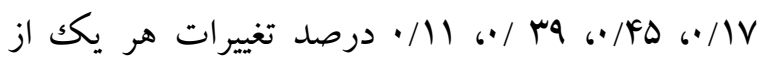
متغيرهاى مجرى مركزى، صفحه ديدارى فضايى، حلقه واج شناختى و شناختى به علت اثر مداخله است. با توجه

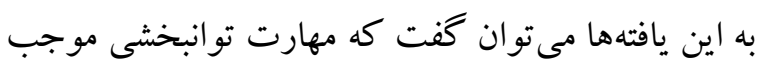
تقويت كار كردهاى شناختى مى گردد. 
ديده را از طريق راهبردهاى آموزشى تكرار و تمرين ترميم كند (اباذرى و همكاران، له شناختى مجموعهاى ساختارمند از اقدامات آموزشى مبتنى بر مهارتهاى حافظه و عملكردهاى شناختى است كه بر تقويت توجه تأكيد دارد و تواناى به ياد آوردن فعاليتهاى روزمره را تقويت مى كند از آن جايى كه تمام فرايندهاى مربوط به آموزش و يادگيرى كه در انجام تكاليف ضرورى هستند با مهارتهاى شناختى ارتباط دارند به نظر مىرسد كه استفاده از توانبخشى شناختى مى تواند مؤثر و مفيد باشد. با توجه به نتايج به دست آمده در اين ويزوهش مى توتوان كفت عليرغم اين كه كاركردهاى اجرايى مبناى زيستى و عصب روانشناختى دارد و عموماً به قشر بيش بيشانى مغز مرتبط است آموزش و ياد كيرى مىتواند در بهبود آنها مؤثر واقع شود. اين موضوع نشاندهنده انعطافيذيرى كاركردهاى اجرايى است. همجنين نقش قابلتوجهى است كه اين كار كردها در بيشرفت تحصيلى ايفا مى كنند. كاركردهاى در نظر گرفته شده در اين يزوهش به ويزه توجه، حافظه فعال، از مهمترين عوامل مؤثر در امر يادگيرى هستند، لذا با بهبود آنها در اثر آموزش تها كاركردهاى اجرايى مىتوان انتظار ارتقاى تحصيلى داشت (عزيزيان و همكاران، وهب 1). در تبيين يافته به دست آمده در اين مطالعه نشان دادند كه آموزش شناختى هم در شناخت و هم در رفتار تأثير دارد، زيرا اين آموزشها، فرايندهاى ذهنى زيربنايى را مورد توجه قرار مىدهند و نارسايىهاى ذهنى كه زير بناى ياد گيرىهاى بعدى هستند، تقويت مى كنند. يافتهاى

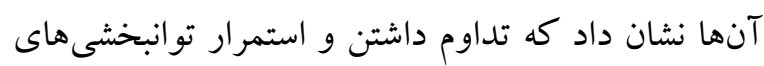
شناختى باعث بهبود توانمندىهاى ذهنى افراد با تاخيرات
خصوص تأثير مثبت و معنىدار توانبخشى شناختى بر

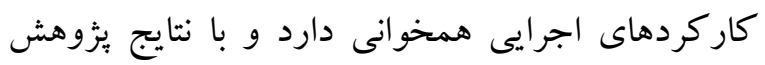

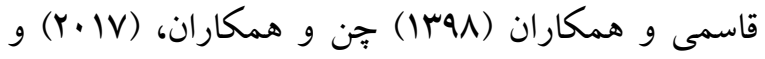

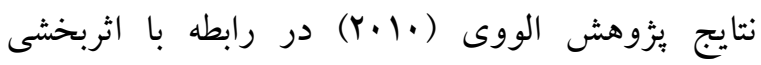
توانبخشى شناختى بر حافظه فعال كودكان با اختلال ياد گيرى همسو است. در يثوهش كفادار و همكاران

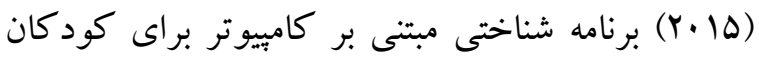

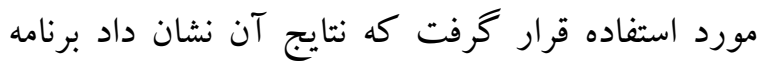
آموزش شناختى براى افزايش هوش تأثير مثتى بر تحول شناختى كود كان دارد. علاوه بر اينها در بيزوهشى ديخر شكوهى يكتا و همكاران اثربخشى برنامه تمرين رايانهاى شناختى بر عملكرد حافظه فعال دانش آموزان نارسا خوان را سنجيدند كه نتايج آن بيانكر تأثير معنىدار اين برنامه بر حافظه فعال ديدارى فضايى بود (شكوهىيكتا، لطفى، رستمى، ارجمند نيا، معتمد يگانه و شريفى، سوس| ) تمر كز اصلى تو انبخشى شناختى بر درمان و يا جبر ان ناتوانىهاى شناختى است. مبناى بهبود نقايص شناختى از طريق تو انبخشى شناختى خاصيت انعطاف يذيرى عصبى مغز است. بر اساس اين خاصيت، مداخله توانبخشى شناختى موجب افزايش ارتباطهاى سينايسى بين نرونها و بهبود كاركرد شناختى از دست رفته مىشود. رويكردهاى توانبخشى شناختى دامنهاى از نقايص (كنترل توجه، حافظه فعال، توانايى فضايى و كنترل مهارى) را مورد هدف قرار دادهاند. جنين آموزشهايى عموماً از طريق رايانها و با استفاده از روندهاى تطابقى صورت مى گيرند كه به موجب آن، دشوارى تكاليف به طور خودكار در سرتاسر جلسات درمانى افزايش مىيابد و عملكرد مراجع به طور مدام به جالش كشيده مىشود. از سوى ديخر برنامه توانبخشى شناختى مىتواند كاركردهاى آسيب 
شخصيتى آنها توجه شود، سواد و وضعيت اقتصادى و اجتماعى آنها مد نظر قرار گيرد.

سياسگز ارى

لازم است از همكارى صميمانه مسئولان آموزش و و برورش و مدير و معلمان كه با صبر و حوصله بسيار ما را در اجراى بهتر يُوهش حاضر يارى كردند، تقدير و تشكر به عمل آوريم. اين مقاله از پيايان نامه دورهى

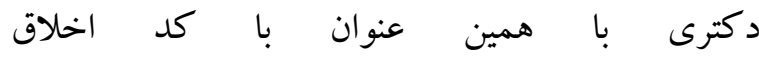
IR.UT.PSYEDU.REC.1399.031 تاريخ Y Y آبان \هبا تصويب شده بود، استخراج شده

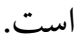

\section{References}

Abazari Gharebelagh K, Mohammadi Darvish Baghal N. (2019). A comparative study of the effectiveness of cognitive rehabilitation intervention with aerobic exercises on the cognition of slow leamer children. Quarterly Journal of Child Mental Health., 6(3): 149161. (In Persian)

Abdolmohamadi K, Alizadeh H, Sourman Abadi Farhad GH, Taiebli M, Fathi A. (2018). Psychometric Properties of Behavioral Rating Scale of Executive Functions (BRIEF) in Children aged 6 to 12 Years Quarterly of Educational Measurement, 105-151. (In Persian)

Alloway TP. (2010). working memory and executive function profiles of individuals with bo borderline intellectual functioning. Joumal of in tell actually disability research.,54(5), 448456.

Amerland E, Esbjomsson E, Sunnerhagen KS, Bjork Dahl A. (2013). Can computerized working memory training improve, impaled Injury, 27(14), 1649-165.
ذهنى مىشود و افراد داراى نارسايى شناختى از مداخلات

در زمينه توانبخشى شناختى سود مىبرند (كورنيش، كل،

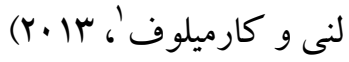

\section{نتيجه كيرى}

مطالب فوق شرحى از اهميت كاركردهاى اجرايى بر عملكرد شناختى دانش آموزان دير آموز بود. اين موضوع مىتواند تا حدود زيادى نقصهاى كاركردهاى اجرايى در اين دانشآموزان را تبين كند كه در صورت برخوردارى از برنامه توانبخشى شناختى خواهند توانست همانند همسالان خود از ظرفيت حافظه شان به نحو مناسبى بهرهمند شوند. جرا كه آموزش از طريق توانبخشى شناختى مبتنى بر كاركردهاى اجرايى موجب بهبود

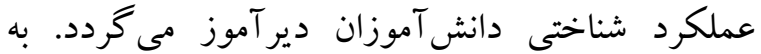
همين دليل، فراهمسازى توصيه مىشود كه ارزيابى و تشخيص دانش آموزان دير آموز زودتر از شروع آموزش رسمى آغاز شود و آموزش كاركردهاى اجرايى به آنها در اولويت مداخلات آموزشى قرار گيرد تا افت تحصيلى آنان در طول تحصيل كاسته شود و همجينين جهت كيرى آموزشى و تربيتى اين دانشآموزان حول محور آموزش خاص در مدارس عادى قرار گيرد. هر ئزوهشى با محدوديتهاى مواجه است اين يُزوهش نيز از جنين قاعدهاى بيروى مى كند بيزوهش حاضر فقط بر روى دانش آموزان دير آموز انجام شد، تأثير متغيرهايى مانند وضعيت اجتماعى و اقتصادى آنها مورد بررسى قرار نخرفت، با توجه به محدوديت زمانى، فرصتى براى اجراى آزمون بيخيرى فراهم نشد؛ بنابراين بيشنهاد مى شود كه در

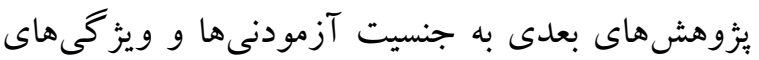

\footnotetext{
1. Cornish, Cole, Longhi, Karmiloff-Smith
} 
Arjmandnia A, Ghasemi S. (2019). Manual of Education-Rehabilitation package for Excutive Functions (BETA). Rushed far hang. Tehran. (InPersian)

Arjmandnia A, Rafikhah M. (2015). The Role of working memory on the performanc of Executive functions in students with leaming disabilities.cognitive Joumal of Psychology and Psychiatry, 3(1): 31-34. (In Persian)

Arjmandnia A. (2017). Working Memory BatteryChildren (WMTB-C). Roshde farhang, Tehran. (InPersian)

Ashori A, Tajvar Rostami A. (2020). Effect of cognitive rehabilitation program based on memory on the workingmemory profile and prospective memory in hearing loss students. Shenakht Journal of Psychology and Psychiatry,6(6),4054. (In Persian)

Azizian M, Asadzadeh H, Alizadeh H, Dortag F, Sadipour E. (2017). Developing and Implementing an Educational Package for Training Executive Functions and its Effectiveness on underachiever pupils' Academic Achievement. Quarterly. Joumal of Cognitive Strategies in Learning, 15(8), 137114. (In Persian).

Be Pajooh A, Afrooz GH, Lavasani M. (2011). The effect of social skills training on social adjustment and late students' academic performance. Educational Innovation Quarterly, 33(9), 163-186. (In Persian)

Biermann KL, Nix RL, Greenberg MT, Bilal C, Domitrvich CE. (2008). Executive functions and school readiness intervention: Impact، Moderation and mediation in the Head start REDI program. Developmental Psychepathology, 20(3), 821-843.

Chauhan S. (2011). Slow leamers: Their Psychology and educational programs. Journal of Multidisciplinary Research, 1(8), 279-289.

Chen X, Ye M, Chang W, Zhou R. (2017). Effect of working memory updating training on retrieving symptoms of children with learning disabilities. Journal of learning disabilities, 113.
Comish K, Cole V, Longhi E, Karmiloff-Smith A. (2013). Scerif G.Mapping development trajectories of attention and working memory in fragile X syndrome:developmental freeze or developmental change? Dev Psychopathol, 25(2): 365-376.

Ghasemi S, Arjmandni A, Lavasan M. (2019). Designing family-based cognitive rehabilitation package and evaluating itseffectiveness on executive functions of dyslexic students. Empowering Exceptional Children, 10(2), 200-215. (In Persian)

Hanssen KT, Brisk AG, Lander NI, Hofoss D, Hessen E. (2016). Cognitive rehabilitation in multiple sclerosis a randomized controlled trial. Act neurological Scandinavia, 133(1), 40-30.

Kafadar H, Akinci Z, Cakir B. (2015). Effects of the IQ up cognitive development method on the cognitive development of 10- to 12-year-old children. Procedia Soc Behav Sci, 174, 3243 3253.

Kanellopoulos A, Andersson S, Zeller B, Tamnes CK, Fjell AM, Walhovd KB, Westlye LT, Fossa SD, \& Ruud E. (2016). Neurocognitive outcome in very long term survivors of childhood acute lymphoblastic leukemia after treatment with chemotherapy only. Pediatric Blood \& Cancer, 63(1), 133-138.

Khanjani Z, Farhoudi M, Nazari MA, Saeedi MT, Abravani P. (2017). Effectiveness of cognitive rehabilitation on selective and divided attention and executive function in adults with stroke cognitive. Joumal of Psychology and Psychiatry, 5(3), 81-94. (In Persian)

Lan X, Legare CH, Ponitz CC, li S, Morrison FJ. (2011). Investigating the links between the subcomponents of executive function and academic achieve Ent: A cross-cultural analysis of Chinese and American preschoolers. Joumal of Experimental Child Psychology, 108(3), 677-692.

Musazadeh Moghaddam H, Arjmandnia A, Afrooz GH, Ghobari-Bonab B. (2019). Prospective Memory Based Cognitive Rehabilitation: ActiveAttention and Memory in Children 
with Hyperactivity Disorder. Archives of Rehabilitation, 20(2), 174-189.(In Persian)

Najarzadegan M, Nejati V, Amiri N, Sharifian M. (2015). Effect of cognitive rehabilitation on executive function (working memory and attention) in children with Attention Deficit Hyperactivity Disorder. J Rehab Med, 4(2), 97-108.

Nazari MA, Dadkhah M, Hashemi T. (2016). Effectiveness of Cognitive Rehabilitation on Dictation Errors of Students with Dysgraphia. J Res Rehabil Sci,11(1), 32. 41. In Persian)

Roporik I. (2014). Do executive functions predict the ability to leam problem solving principles? Intelligence, 44, 6474.

Sadh S, Bums Matthew K, and Sullivan, Amend L. (2012). Examining an Executive Function Rating Scale as predictor of achievement in children at risk for Behavior problems. School psychology Quarterly, 1704, 236-246.

Salvador-Corella L, Garcia- Gutierrez C, GIGWierrezColosia MR, Artigas-pillars j, Ibanez JG, Perez JG, Pal MMN, Ines FA, Issus S, Cerise JM, Poole M, Lozano GP, Monsoon P, Leyva M, paroled MM, Novell KG, Hemandez AM, Rig $\mathrm{Au} \mathrm{E,} \mathrm{Martinez-} \mathrm{Leal} \mathrm{R.} \mathrm{(2013).}$ Borderline Intellectual Functioning: Consensus and good practice Guidelines. Revisit desi quiet vial Saluda Mental (Bark), 6(3), 109- 120.

Seguin M, Lachaise A, Matte-Gagne C, Beauchamp MH. (2017). Ready! Let 'train! Feasibility of an intensive attention training program and its beneficial effect after childhood traumatic brain injury. Annals of physical and rehabilitation medicine, 8,1-8.

Shokoohi-YektaM, Lotfi S, Rostami R, Arjmandnia A, Negin Motamed-Yeganeh N, Sharifi A. (2015). The effectiveness of computerized cognitive training on the working memory performance of children with dyslexia, 23(3), 46-56. (In Persian)

Vasudevan A. (2017). Slow leamers Causes, problems and educational programs, 3(12), 308-316.

Widyaningtyas D, Mashluhah M, \& Hrtini A. (2017). Learning strategies for slowleamers using the project based leaming model in primary school. Journal pendaikan inklus, 1(1), 29-39. Yavari E, Askari Parviz A, Naderi Farah N, Alirezah H. (2019). Effect of Cognitive Rehabilitation Therapy on Performance (Memory and Problem Solving) of Children with Attention Deficit Hyperactivity Disorder. J Rehab Med, 8(4), 165-176. (In Persian) 